Article

\title{
Diagenetic Origin of Bipyramidal Quartz and Hydrothermal Aragonites within the Upper Triassic Saline Succession of the Iberian Basin: Implications for Interpreting the Burial-Thermal Evolution of the Basin
}

\author{
María J. Herrero ${ }^{1, *(\mathbb{D}}$, Rafaela Marfil ${ }^{1}$, Jose I. Escavy ${ }^{2}{ }^{\circledR}$, Ihsan Al-Aasm ${ }^{3}\left(\mathbb{C}\right.$ and Michael Scherer ${ }^{4}$ \\ 1 Departamento de Mineralogía y Petrología, Facultad CC. Geológicas, Universidad Complutense de Madrid, \\ 28040 Madrid, Spain; marfil@ucm.es \\ 2 Departamento de Ingeniería y Morfología del Terreno Escuela Técnica Superior de Ingenieros de Caminos, \\ Canales y Puertos, Universidad Politécnica de Madrid, 28040 Madrid, Spain; ji.escavy@upm.es \\ 3 School of the Environment, University of Windsor Ontario, Windsor, ON N9B 3P4, Canada; \\ alaasm@uwindsor.ca \\ 4 GG Consulting, 46282 Dorsten, Germany; mscherer1025@yahoo.com \\ * Correspondence: mjherrer@ucm.es
}

Received: 30 December 2019; Accepted: 12 February 2020; Published: 15 February 2020

\begin{abstract}
Within the Upper Triassic successions in the Iberian Basin (Spain), the occurrence of both idiomorphic bipyramidal quartz crystals as well as pseudohexagonal aragonite crystals are related to mudstone and evaporite bearing sequences. Bipyramidal-euhedral quartz crystals occur commonly at widespread locations and similar idiomorphic crystals have been described in other formations and ages from Europe, America, Pakistan, and Africa. Similarly, pseudohexagonal aragonite crystals are located at three main sites in the Iberian Range and are common constituents of deposits of this age in France, Italy, and Morocco. This study presents a detailed description of the geochemical and mineralogical characteristics of the bipyramidal quartz crystals to decipher their time of formation in relation to the diagenetic evolution of the sedimentary succession in which they formed. Petrographic and scanning electron microscopy (SEM) analyses permit the separation of an inner part of quartz crystals with abundant anhydrite and organic-rich inclusions. This inner part resulted from near-surface recrystallization (silicification) of an anhydrite nodule, at temperatures that were $<40^{\circ} \mathrm{C}$. Raman spectra reveal the existence of moganite and polyhalite, which reinforces the evaporitic character of the original depositional environment. The external zone of the quartz contains no anhydrite or organic inclusions and no signs of evaporites in the Raman spectra, being interpreted as quartz overgrowths formed during burial, at temperatures between 80 to $90{ }^{\circ} \mathrm{C}$. Meanwhile, the aragonite that appears in the same Keuper deposits was precipitated during the Callovian, resulting from the mixing of hydrothermal fluids with infiltrated waters of marine origin, at temperatures ranging between 160 and $260^{\circ} \mathrm{C}$ based on fluids inclusion analyses. Although both pseudohexagonal aragonite crystals and bipyramidal quartz appear within the same succession, they formed at different phases of the diagenetic and tectonic evolution of the basin: bipyramidal quartz crystals formed in eo-to mesodiagenetic environments during a rifting period at Upper Triassic times, while aragonite formed $40 \mathrm{Ma}$ later as a result of hydrothermal fluids circulating through normal faults.
\end{abstract}

Keywords: bipyramidal quartz; pseudohexagonal aragonite; Iberian Range; Upper Triassic; diagenesis; hydrothermal circulation 


\section{Introduction}

Within the Upper Triassic sequences in the Iberian Basin, Spain (Figure 1a), and in other European countries, the occurrence of both bipyramidal quartz crystals (Figure 1b) and pseudohexagonal aragonite crystals (Figure 1c) is common within mudstone, evaporites, and marls that represent saline mudflats and salt pond facies. The aragonite crystals occur associated with outcrops of pre-Hettangian alkaline magmatism and related to normal faults dated as Middle-to-Upper Jurassic. Their formation resulted from the mixing of infiltrated marine waters with hydrothermal fluids that circulated synrift faults [1]. The quartz crystals, on the contrary, appear in a wider range of locations (Figure 1a) with no close relation to major faults or volcanic deposits. Instead, they appear to be related to facies rich in organic matter and have numerous saline mineral inclusions, indicating that the original sediments formed in environments under strong evaporitic conditions.

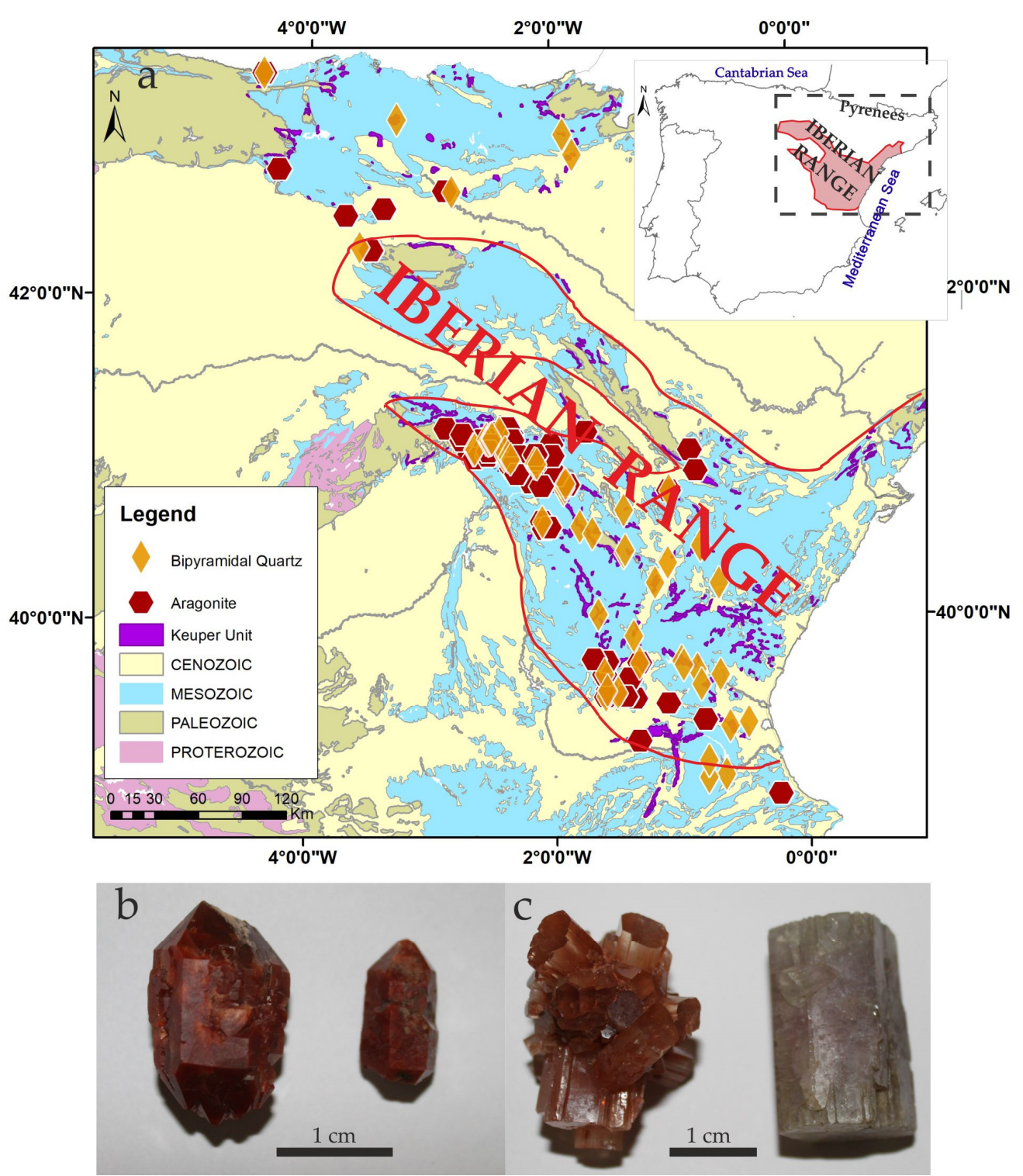

Figure 1. (a) Location of the bipyramidal quartz and aragonite crystals in the Iberian Range (Spain); (b) Bipyramidal quartz crystals that commonly are red-colored; (c) Pseudohexagonal aragonite prisms and rosettes, which show a wider color variation. 
Euhedral quartz crystals, also named megaquartz crystals [2], have been described in the geological record within carbonate strata [3], normally as minor constituents [2,4-8]. They commonly appear related to sequences formed under evaporitic conditions [5,9-11] in dolomitic and salty sediments. It is, therefore, necessary to include the associated lithologies in the study. In the Iberian Peninsula, the occurrences of bipyramidal quartz are taken as indicators of the evaporitic Keuper (Upper Triassic) facies [12]. These are commonly known in Spain as "Jacintos de Compostela" [13].

Megaquartz crystals appear in Pleistocene and ancient sabkha dolomite accumulations from the Arabian Gulf, and their origin has been determined as resulting from dolomite and evaporite precursors replaced by silica in near-surface environments [5] during early diagenesis [2,14]. Such types of megaquartz crystals are found as well in Ukraine, Norway, Pakistan, and China [15]. The Herkimer diamonds [16], formed in a shallow marine Cambro-Ordovician succession, were interpreted as cements within cavities formed by dissolution produced from the flow of acidic water. Hexagonal crystals grew in the cavities very slowly, resulting in doubly terminated quartz crystals of exceptional clarity. The main factor controlling the carbonates silicification has been interpreted as fluctuations in $\mathrm{pH}$ around a value of 9 , due to the inverse solubility relationship of silica and calcite $[17,18]$. Other factors are salinity changes in the pore fluids as well as the amount of host rock porosity and groundwater circulation [17].

Therefore, considering that authigenic quartz crystals and pseudohexagonal aragonites both appear within the same Keuper facies, the comparison of time, genesis, and factors controlling their formation should indicate variations in the tectonic evolution, i.e., rise and subsidence, and hence, in the thermal history of the basin.

\section{Geological Setting}

The Permo-Triassic Iberian Basin is a NW-SE trending rift transect that has been generally considered to be related to two main rifting cycles followed by post-rift periods of thermal subsidence [19-22]. The first rifting stage (Figure 2) occurred during the break-up of Pangea [23] between the early Permian and the Middle Triassic [24]. The second main cycle (Figure 2) spanned the late Jurassic to early Cretaceous and has been linked to the separation of Africa from Europe, and the simultaneous anticlockwise rotation of the Iberian Plate [25,26].

The current Iberian Range (Figure 1a) resulted from the tectonic inversion of the Iberian Basin and the up thrusting of basement rocks during the Pyrenean orogeny [27]. Basement uplifts, 5 to $30 \mathrm{~km}$ wide, are bounded by major NW-SE striking steeply dipping reverse faults, which were reactivated Variscan normal faults [28]. The Keuper succession (late Ladinian-early Carnian to Norian-Rhaetian) was formed during a post-rifting subsidence stage with minor tectonic activity [29]. The sedimentary sequence resulted from marine incursions during a transgressive period [30], first into narrow corridors and later surrounding the highest areas of the flanks [27]. The Keuper succession crops out with variable thicknesses and shows strong deformation due to its ductile character [31].

Five sequences (K1 to K5) compose the Spanish Keuper succession. K1, known as the "Lower Evaporitic Series", is a 40 to $380 \mathrm{~m}$ thick alternation of laminated gypsum and mudstone beds, with layers of sandstone, marl, and carbonates that represent lagoons and shallow coastal salinas [33,34]. $\mathrm{K} 2$ consists of $c a 15 \mathrm{~m}$ of red and yellow mudstones with interbedded dolomite beds formed within fluvial and lacustrine environments. The third sequence, $\mathrm{K} 3$, consists of a $c a 45 \mathrm{~m}$ succession of red mudstone that accumulated in a muddy intertidal setting [35]. Finally, the K4 and K5 units compose the "Upper Evaporitic Series", being K4 a 60 to 150 m-thick red mudstone sequence with abundant nodular gypsum deposited in coastal sabkhas, and $\mathrm{K} 5$ (up to $50 \mathrm{~m}$ thick) is mostly white-bedded gypsum, with interbedded mudstones deposited in evaporitic lagoons [36]. In the Iberian Peninsula, these saline deposits are the most abundant, covering $4394 \mathrm{~km}^{2}$ [37,38]. The studied bipyramidal quartz and aragonite crystals are found in the topmost part of the evaporite-mudstone deposits of the K4 unit. 


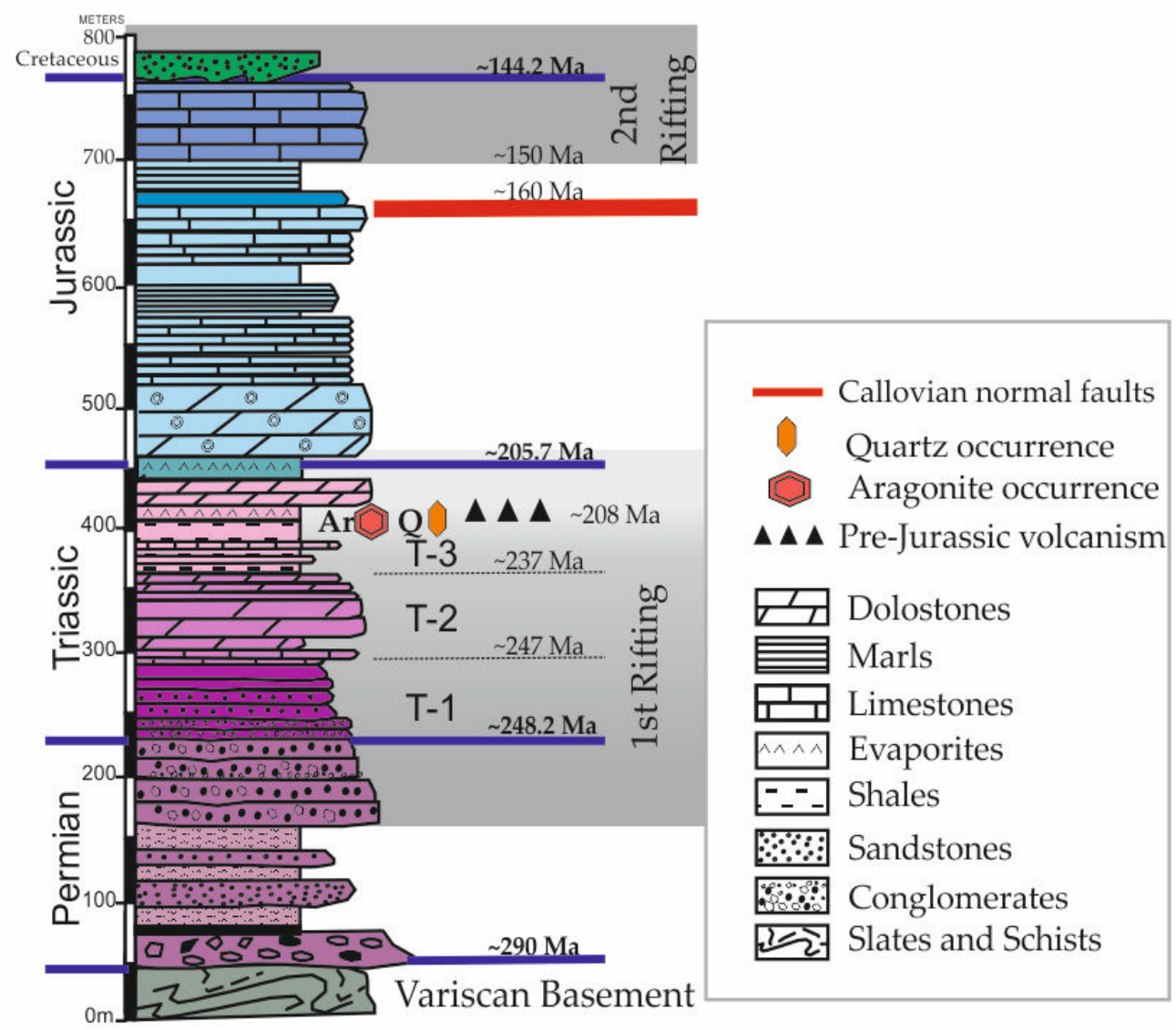

Figure 2. Upper Permian to Lower Cretaceous stratigraphic section in the Iberian Basin (lithology, thickness, and ages) and position of the occurrences of aragonite (Ar) and authigenic quartz (Q). Dates of the pre-Hettangian volcanism and the 1st and 2nd Rifting periods are indicated [32] (T-1: Buntsandstein; T-2: Muschelkalk; T-3: Keuper; Modified from [1].

The overlying Imón Formation represents an epicontinental carbonate platform [39] of pre-Hettangian age. Different magmatic episodes occurred from the Middle and Upper Triassic to Jurassic times [23]. The magmas were of tholeiitic and alkaline affinities, being pre-Hettangian volcanism commonly associated with the Imón Formation (Figure 2), characterized by sub-volcanic tabular bodies (sills) that intruded into the K4 and K5 units of the Keuper [40].

\section{Materials and Methods}

Analyses of 30 representative bipyramidal quartz crystals from selected outcrops located in the Iberian Range in the K4 unit of the Keuper Facies (Figure 2) were performed. Thin sections were prepared to distinguish between quartz and inclusions of different minerals. Sequential relationships were established between different phases. For petrographic studies, samples were cut with an oil-cooled diamond disc saw (Struers Discoplan-TS; Struers ApS, Ballerup, Denmark).

Bulk mineralogy of the powdered quartz crystals was determined by powder X-ray diffraction (XRD), employing a Philips PW 1720 diffractometer with $\mathrm{Cu}(\mathrm{K} \alpha)$ radiation and a Bruker D8 Advance diffractometer equipped with a Sol-X detector and $\mathrm{Cu}(\mathrm{K} \alpha)$ radiation (Bruker, Billerica, MA, USA). The mineralogical composition of crystalline phases was estimated following the Chuns [41] method and using Bruker software (EVA) at CAI de Técnicas Geológicas, Universidad Complutense de Madrid (UCM).

The occurrence and the textural relationship between quartz crystals and their inclusions were studied using a scanning electron microscope (SEM) coupled with energy-dispersive spectrometry 
(EDS). For the SEM analyses, it has been used the model JEOL JSM 6400 equipped with an Oxford energy-dispersive X-ray micro analyzer (JEOL Limited, Tokyo, Japan) both in secondary electron (SE) and backscattered electron modes (BSE) was used. SEM-cathodoluminescence microscopy has been used to distinguish between (1) quartz (as several phases of quartz overgrowths), and (2) inclusions within quartz crystals [42]. SEM-cathodoluminescence (SEM-CL) colors in quartz have been related to the presence of activator trace elements, lattice order, and crystallization temperature [42,43]. SEM-CL observations were done on carbon-coated polished thin sections using a JEOL JSM-840 electron microscope equipped with a Gatan ChromaCL2 housed at the CAI de Técnicas Geológicas, UCM.

Microprobe mineral analyses on polished quartz crystal surfaces were performed to obtain additional data to determine the geochemical composition and decipher diagenetic processes. The chemical composition of inclusions in quartz crystals was analyzed by ion microprobe analyses (EPMA) using a JEOL JXA-8900 model. Operating conditions were characterized by voltage $15 \mathrm{kV}$, current intensity $20 \mathrm{nA}$, and electron beam diameter $5 \mu \mathrm{m}$. Detection limits were ca $150 \mathrm{ppm}$ for Ca, $100 \mathrm{ppm}$ for $\mathrm{Mg}$, 250 ppm for $\mathrm{Mn}, 300$ ppm for Fe, and 250 for $\mathrm{Sr}$ and Ba. Analytical totals were normalized to $100 \%$ moles of $\mathrm{CaCO}_{3}, \mathrm{SO}_{3}, \mathrm{MgCO}_{3}, \mathrm{FeCO}_{3}, \mathrm{TiO}_{2}, \mathrm{BaO}, \mathrm{Al}_{2} \mathrm{O}_{3}$, and $\mathrm{MnO}$ for comparison. These analyses were performed at the Centro Nacional de Microscopía electrónica (CNME).

Raman spectral analysis of samples was performed on an XRD confocal Raman Thermo Fischer Microscope at the Spectroscopy CAI, UCM. Excitation was provided by the $532 \mathrm{~nm}$ line of a diode laser.

\section{Results}

\subsection{Petrographic Analyses}

The quartz crystals appear as individual euhedral crystals or as clusters of crystals. Detailed petrographic analyses were used to characterize their textures.

Single crystals were either double terminated or had a well-developed single termination and well-defined crystal faces. Single crystals ranged from $0.0625 \mathrm{~mm}$ to $2.6 \mathrm{~cm}$ lengths (Figure $1 \mathrm{~b}$ ), while cluster appeared as groupings of quartz crystals that converged in a nucleus (Figure 1b). Petrographic analyses revealed that the center of the crystal had numerous evaporate mineral inclusions (Figure 3a) resembling anhydrite laths (Figure 3b,c) and radial-pattern inclusion filled by organic matter (Figure 3d,e). These inclusions appeared in a circular distribution (Figure 3c). Towards the edges, the crystal was zoned and free of inclusions (Figure 3a,f-h). Generally, all the inclusions with prismatic or needle shapes appeared to be filled by anhydrite, and all of them had the same extinction which appeared to be originated by the replacement of one single anhydrite crystal. Variations in the number of inclusions permitted the determination of a discontinuous zoning that formed bands (Figure 3a,d). There were at least 5 bands of zonation (Figure 3a), considered as potential crystal overgrowths.

Optical images (Figure 3c,d) showed subangular to round quartz grains (red line) in the center of the quartz crystals. Clusters of crystals embedded in a carbonate (calcite) poikilotopic cement occurred as well. There were also dispersed crystals of pyrite and chalcopyrite.

\subsection{Geochemical Analyses}

Microprobe analyses (Table 1) showed that the composition of quartz crystals was almost totally $\mathrm{SiO}_{2}$, with a mean value of $98.14 \%(n=53)$. The second highest component was $\mathrm{Al}_{2} \mathrm{O}_{3}$ with average percentages of $0.11 \%$. Minor contents of $\mathrm{Fe}_{2} \mathrm{O}_{3}, \mathrm{MnO}, \mathrm{CaO}$, and $\mathrm{MgO}$ were present. Microprobe measurements of $\mathrm{Al}_{2} \mathrm{O}_{3}$ along a transect from the center to the edges of the quart generally varied from lower contents in the inner part of the crystal (Figure $4 \mathrm{a}-\mathrm{d}$ ) and a progressive rising towards the outer part (Figure $4 \mathrm{~b})$. Geochemical analysis performed within the inclusions $(n=15)$ indicated that they were dominantly composed of $c a 52.81 \%$ of $\mathrm{CaO}$ and $\mathrm{ca} 0.8 \%$ of $\mathrm{SO}_{3}$, with minor amounts of $\mathrm{FeO}$ $(0.39 \%), \mathrm{MgO}(0.2 \%)$, and $\mathrm{SiO}_{2}(0.36 \%)$. Other inclusions near the detection limit appeared filled by anhydrite and organic matter. 

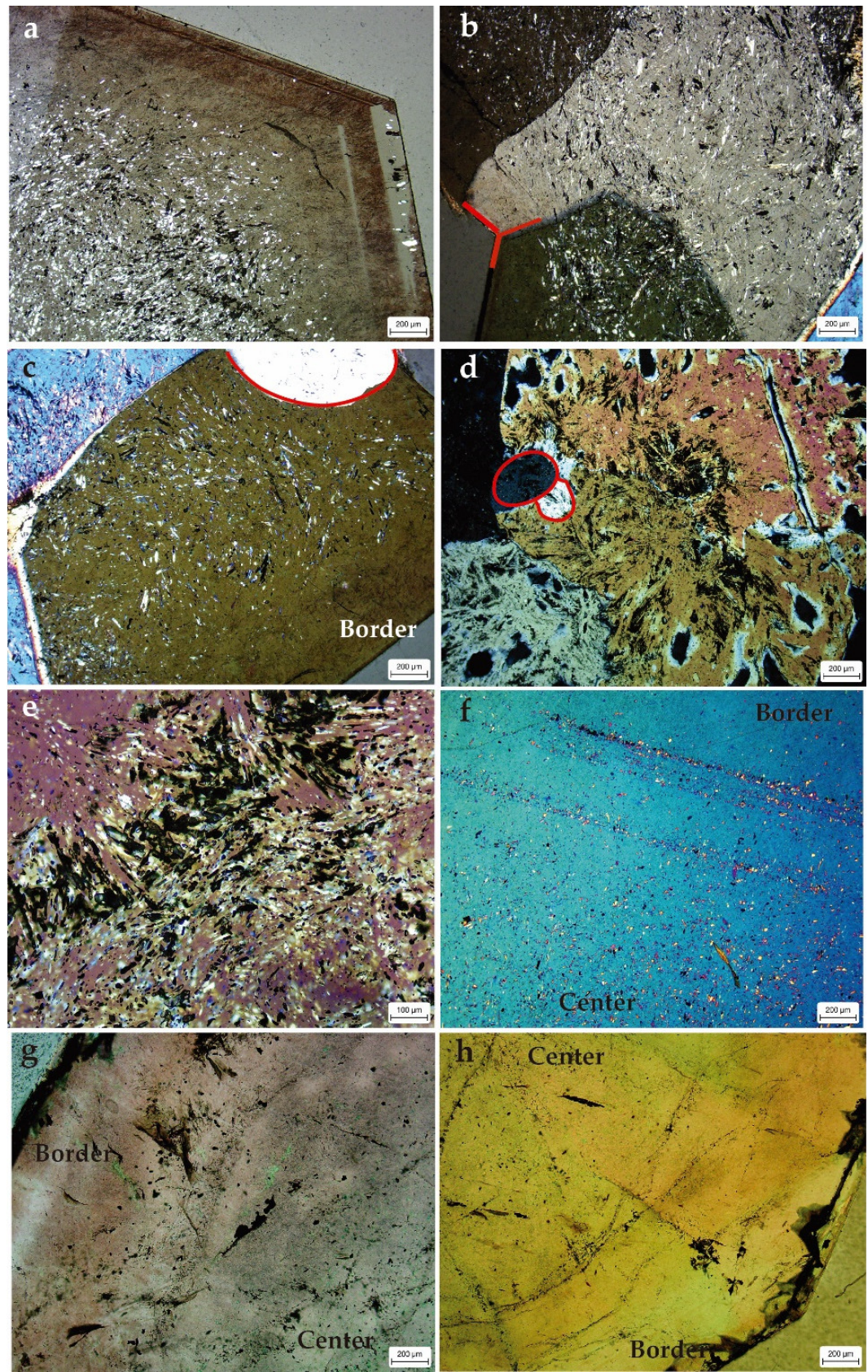

Figure 3. Euhedral quartz with hexagonal crystal shapes: (a) Cross-polarized light of a quartz crystal with abundant inclusions in the center and idiomorphic overgrowth towards the edges of the crystal; (b) Cross-polarized image of the quartz crystals, with crystal triple junctions (in red) that are clear and free of inclusions; (c) Cross-polarized image of another crystal where the pattern of the inclusion can be observed; (d) Cross-polarized image of the center of the crystal with abundant inclusions that change to bands free of inclusions towards the outer part; (e) Detail of the center of the crystal and the texture of the organic-rich inclusion; (f) Patches of elongate inclusions filled with organic matter and anhydrite laths in the central part of the crystal; (g) Plane-polarized light where the concretional morphology of the interior of the quartz marked by lineation of the organic matter inclusions. The external part of the crystal is free of inclusion; (h) Quartz appeared as idiomorphic crystals, although the inclusions-rich inner part revealed a dissolution surface in the interior of the crystal. To avoid the destruction of inclusions, thin sections were kept thicker and consequently changed the quartz interference colors in polarized light. 
Table 1. Microprobe analyses of quartz crystals (the values are in $w t \%$ ). Numbers of measurement points are valid for Figure 4.

\begin{tabular}{|c|c|c|c|c|c|c|c|c|c|c|c|c|}
\hline & Point & $\mathrm{SiO}_{2}$ & $\mathbf{A l}_{2} \mathbf{O}_{3}$ & $\mathrm{FeO}$ & MnO & $\mathrm{MgO}$ & $\mathrm{CaO}$ & $\mathrm{Na}_{2} \mathrm{O}$ & $\mathbf{K}_{2} \mathbf{O}$ & $\mathrm{TiO}_{2}$ & $\mathrm{SO}_{3}$ & $\mathbf{B a O}$ \\
\hline BO17 & 1 & 99.52 & 0.29 & 0.12 & 0 & 0.01 & 0 & 0 & 0.02 & 0.01 & 0.03 & 0 \\
\hline BO17 & 2 & 99.67 & 0.24 & 0.04 & 0 & 0 & 0.01 & 0 & 0.01 & 0 & 0.01 & 0.02 \\
\hline BO17 & 3 & 99.72 & 0.27 & 0.01 & 0 & 0 & 0 & 0 & 0 & 0 & 0 & 0 \\
\hline BO17 & 4 & 99.78 & 0.05 & 0 & 0.06 & 0.02 & 0 & 0 & 0.02 & 0 & 0 & 0.07 \\
\hline BO17 & 5 & 99.92 & 0 & 0 & 0 & 0 & 0 & 0 & 0.02 & 0.01 & 0.04 & 0.01 \\
\hline BO17 & 6 & 99.83 & 0.02 & 0 & 0.02 & 0 & 0.03 & 0 & 0.01 & 0 & 0.01 & 0.08 \\
\hline BO17 & 7 & 99.89 & 0.02 & 0 & 0.01 & 0.01 & 0.03 & 0 & 0.01 & 0.02 & 0.01 & 0 \\
\hline BO17 & 8 & 99.68 & 0.10 & 0.07 & 0 & 0 & 0.03 & 0 & 0 & 0.03 & 0 & 0.09 \\
\hline BO17 & 9 & 99.85 & 0.04 & 0.03 & 0.03 & 0 & 0 & 0.02 & 0.01 & 0 & 0.02 & 0 \\
\hline BO17 & 10 & 99.84 & 0.04 & 0.02 & 0 & 0.01 & 0.01 & 0.01 & 0.01 & 0 & 0.03 & 0.03 \\
\hline BO17 & 11 & 99.88 & 0.04 & 0 & 0 & 0 & 0.03 & 0.01 & 0.02 & 0.01 & 0.01 & 0 \\
\hline BO17 & 12 & 99.78 & 0.04 & 0.05 & 0 & 0 & 0 & 0.01 & 0.01 & 0.01 & 0 & 0.10 \\
\hline BO17 & 13 & 99.89 & 0.04 & 0.03 & 0 & 0 & 0 & 0.01 & 0 & 0.02 & 0.01 & 0 \\
\hline BO17 & 14 & 99.8 & 0.10 & 0.02 & 0 & 0.01 & 0.01 & 0 & 0.02 & 0.02 & 0.02 & 0 \\
\hline BO17 & 15 & 99.8 & 0.11 & 0.01 & 0.02 & 0 & 0 & 0.01 & 0 & 0 & 0 & 0.05 \\
\hline BO17 & 16 & 99.87 & 0.07 & 0 & 0 & 0 & 0.01 & 0 & 0 & 0 & 0 & 0.05 \\
\hline BO17 & 17 & 99.74 & 0.11 & 0.02 & 0 & 0.02 & 0 & 0.01 & 0 & 0.01 & 0.04 & 0.05 \\
\hline BO17 & 18 & 99.58 & 0.25 & 0.05 & 0.03 & 0.01 & 0.02 & 0 & 0.01 & 0 & 0.01 & 0.04 \\
\hline BO17 & 19 & 99.5 & 0.49 & 0 & 0 & 0.01 & 0 & 0 & 0 & 0 & 0 & 0 \\
\hline BO17 & 20 & 99.4 & 0.48 & 0.07 & 0 & 0 & 0.02 & 0 & 0 & 0 & 0 & 0.03 \\
\hline BO17-1 & 25 & 99.9 & 0.05 & 0.01 & 0 & 0.01 & 0.02 & 0 & 0.01 & 0 & 0 & 0 \\
\hline BO17-1 & 26 & 99.81 & 0.09 & 0.01 & 0 & 0 & 0.01 & 0.02 & 0.01 & 0 & 0 & 0.05 \\
\hline BO17-1 & 27 & 99.92 & 0.02 & 0.03 & 0 & 0 & 0 & 0 & 0 & 0.03 & 0 & 0 \\
\hline BO17-1 & 28 & 99.88 & 0 & 0.05 & 0.03 & 0 & 0 & 0 & 0 & 0 & 0 & 0.04 \\
\hline BO17-1 & 31 & 99.84 & 0.06 & 0 & 0 & 0 & 0.01 & 0 & 0 & 0 & 0.02 & 0.07 \\
\hline BO17-1 & 32 & 99.67 & 0.17 & 0 & 0 & 0.01 & 0 & 0.02 & 0.01 & 0 & 0 & 0.12 \\
\hline BO17-1 & 33 & 99.7 & 0.14 & 0 & 0 & 0 & 0 & 0 & 0 & 0.01 & 0 & 0.15 \\
\hline BO17-1 & 34 & 99.82 & 0.09 & 0.04 & 0.01 & 0 & 0.01 & 0.01 & 0 & 0.02 & 0 & 0 \\
\hline BO17-1 & 35 & 99.87 & 0.08 & 0 & 0 & 0.03 & 0 & 0 & 0.01 & 0.01 & 0 & 0 \\
\hline BO15 & 36 & 99.78 & 0.07 & 0.06 & 0 & 0 & 0.01 & 0.01 & 0 & 0 & 0 & 0.06 \\
\hline BO15 & 37 & 99.55 & 0.15 & 0.06 & 0 & 0.16 & 0.03 & 0 & 0.01 & 0.01 & 0 & 0.02 \\
\hline BO15 & 38 & 99.85 & 0.04 & 0.07 & 0.01 & 0 & 0 & 0 & 0.02 & 0 & 0 & 0 \\
\hline BO15 & 39 & 99.69 & 0.02 & 0.14 & 0 & 0 & 0.01 & 0.01 & 0.02 & 0.03 & 0.02 & 0.05 \\
\hline BO15 & 40 & 99.84 & 0.10 & 0.01 & 0 & 0.01 & 0 & 0.01 & 0.02 & 0 & 0 & 0.01 \\
\hline BO15 & 41 & 99.89 & 0 & 0 & 0 & 0 & 0 & 0 & 0.02 & 0 & 0.02 & 0.06 \\
\hline BO15 & 42 & 99.77 & 0.11 & 0.04 & 0 & 0 & 0.01 & 0 & 0.01 & 0 & 0 & 0.06 \\
\hline BO15 & 43 & 99.71 & 0.08 & 0.02 & 0 & 0.01 & 0.02 & 0.01 & 0 & 0 & 0 & 0.15 \\
\hline BO15 & 44 & 99.72 & 0.09 & 0.04 & 0.02 & 0 & 0.01 & 0 & 0 & 0 & 0 & 0.11 \\
\hline BO15 & 45 & 99.68 & 0.15 & 0.06 & 0 & 0.01 & 0.02 & 0 & 0.01 & 0 & 0.03 & 0.03 \\
\hline BO15 & 46 & 99.82 & 0.03 & 0.11 & 0.02 & 0 & 0 & 0 & 0.01 & 0 & 0.01 & 0 \\
\hline BO18 & 47 & 99.7 & 0.04 & 0.07 & 0 & 0 & 0 & 0 & 0.10 & 0 & 0.09 & 0 \\
\hline BO18 & 48 & 99.81 & 0.05 & 0.06 & 0 & 0.03 & 0 & 0 & 0.02 & 0.02 & 0.01 & 0 \\
\hline BO18 & 49 & 99.85 & 0.07 & 0.03 & 0 & 0 & 0 & 0 & 0.01 & 0.04 & 0 & 0 \\
\hline BO18 & 50 & 99.77 & 0.02 & 0.07 & 0 & 0 & 0 & 0.01 & 0 & 0.01 & 0.02 & 0.10 \\
\hline BO18 & 51 & 99.8 & 0.07 & 0 & 0.02 & 0.02 & 0 & 0 & 0.01 & 0.04 & 0.04 & 0 \\
\hline BO18 & 52 & 99.68 & 0.16 & 0.12 & 0 & 0 & 0.02 & 0.02 & 0 & 0 & 0 & 0 \\
\hline BO18 & 53 & 99.73 & 0.16 & 0.05 & 0 & 0 & 0.02 & 0.02 & 0.01 & 0 & 0.01 & 0 \\
\hline \multicolumn{2}{|c|}{ Mean } & 99.77 & 0.1 & 0.04 & 0.01 & 0.01 & 0.01 & 0 & 0.01 & 0.01 & 0.01 & 0.04 \\
\hline \multicolumn{2}{|c|}{ Std. Dev. } & 0.12 & 0.11 & 0.04 & 0.01 & 0.02 & 0.01 & 0.01 & 0.02 & 0.01 & 0.02 & 0.04 \\
\hline
\end{tabular}



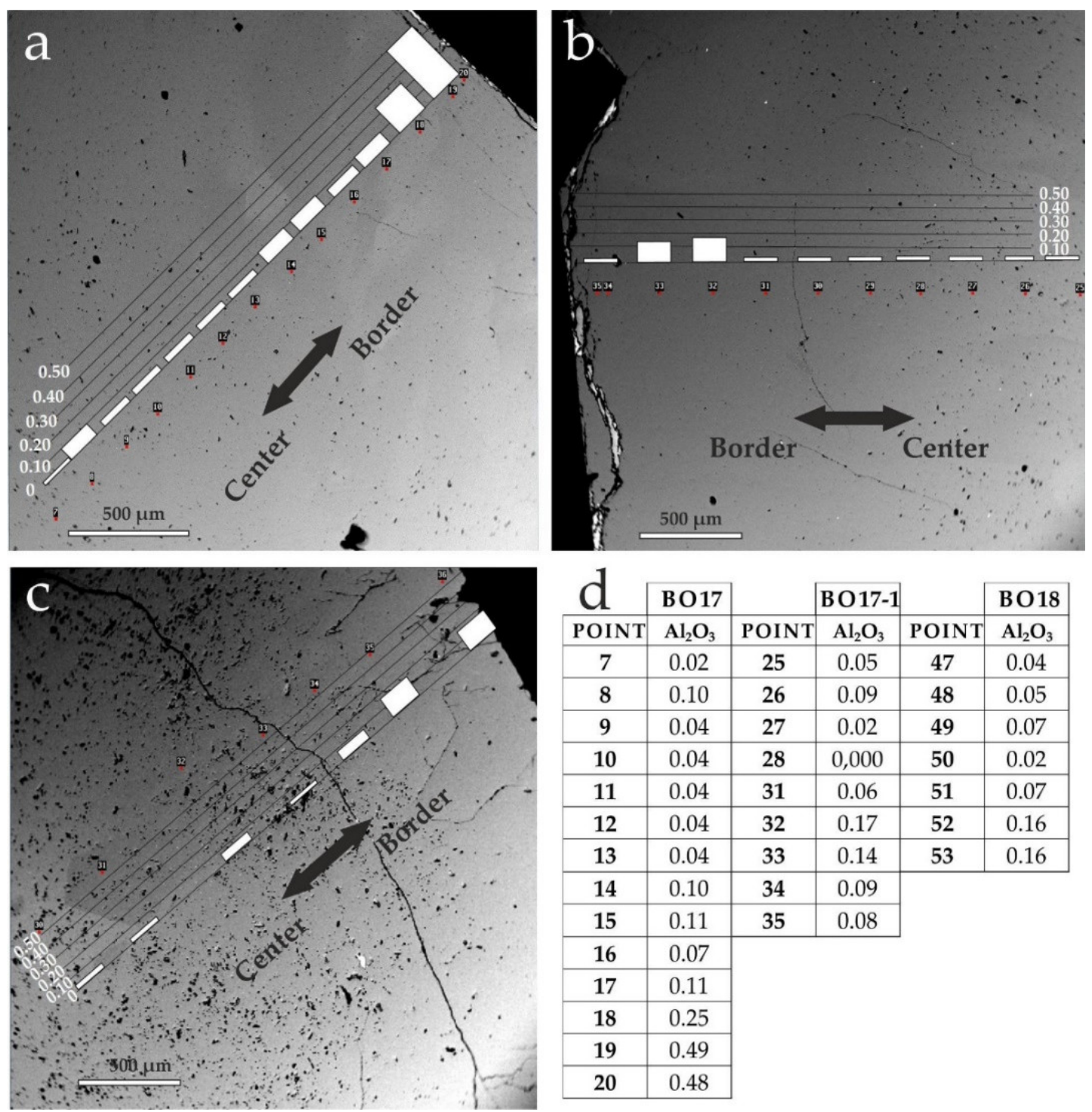

\begin{tabular}{|c|c|c|c|c|c|}
\hline $\mathbf{a}$ & BO17 & \multicolumn{3}{|c|}{ B O 17-1 } & BO18 \\
\hline POINT & $\mathrm{Al}_{2} \mathrm{O}_{3}$ & POINT & $\mathrm{Al}_{2} \mathrm{O}_{3}$ & POINT & $\mathrm{Al}_{2} \mathrm{O}_{3}$ \\
\hline 7 & 0.02 & 25 & 0.05 & 47 & 0.04 \\
\hline 8 & 0.10 & 26 & 0.09 & 48 & 0.05 \\
\hline 9 & 0.04 & 27 & 0.02 & 49 & 0.07 \\
\hline 10 & 0.04 & 28 & 0,000 & 50 & 0.02 \\
\hline 11 & 0.04 & 31 & 0.06 & 51 & 0.07 \\
\hline 12 & 0.04 & 32 & 0.17 & 52 & 0.16 \\
\hline 13 & 0.04 & 33 & 0.14 & 53 & 0.16 \\
\hline 14 & 0.10 & 34 & 0.09 & & \\
\hline 15 & 0.11 & 35 & 0.08 & & \\
\hline 16 & 0.07 & & & & \\
\hline 17 & 0.11 & & & & \\
\hline 18 & 0.25 & & & & \\
\hline 19 & 0.49 & & & & \\
\hline 20 & 0.48 & & & & \\
\hline
\end{tabular}

Figure 4. Electron backscatter images of the quartz samples: they were mostly composed of silica (88\%). (a) Sample BO17; (b) Sample BO17-1; and (c) Sample BO18. $\mathrm{Al}_{2} \mathrm{O}_{3}$ appeared as $c a$ 0.11\%, but slight variations were detected from lower values in the center towards higher values to the edges of the crystals; (d) $\mathrm{Al}_{2} \mathrm{O}_{3}$ values represented in the three $a, b, c$ lines of the figure (for microprobe data see Table 1).

\subsection{Scanning Electron Microscope Analyses}

SEM analyses of the quartz crystals showed clearly a lack of abrasion caused by transportation (Figure 5a). No sign of dissolution processes was indicated by sharp crystal terminations and edges. There were anhydrite inclusions (Figure $5 b$ ) and lath patterns in the center of the quartz crystals (Figure 5c). 

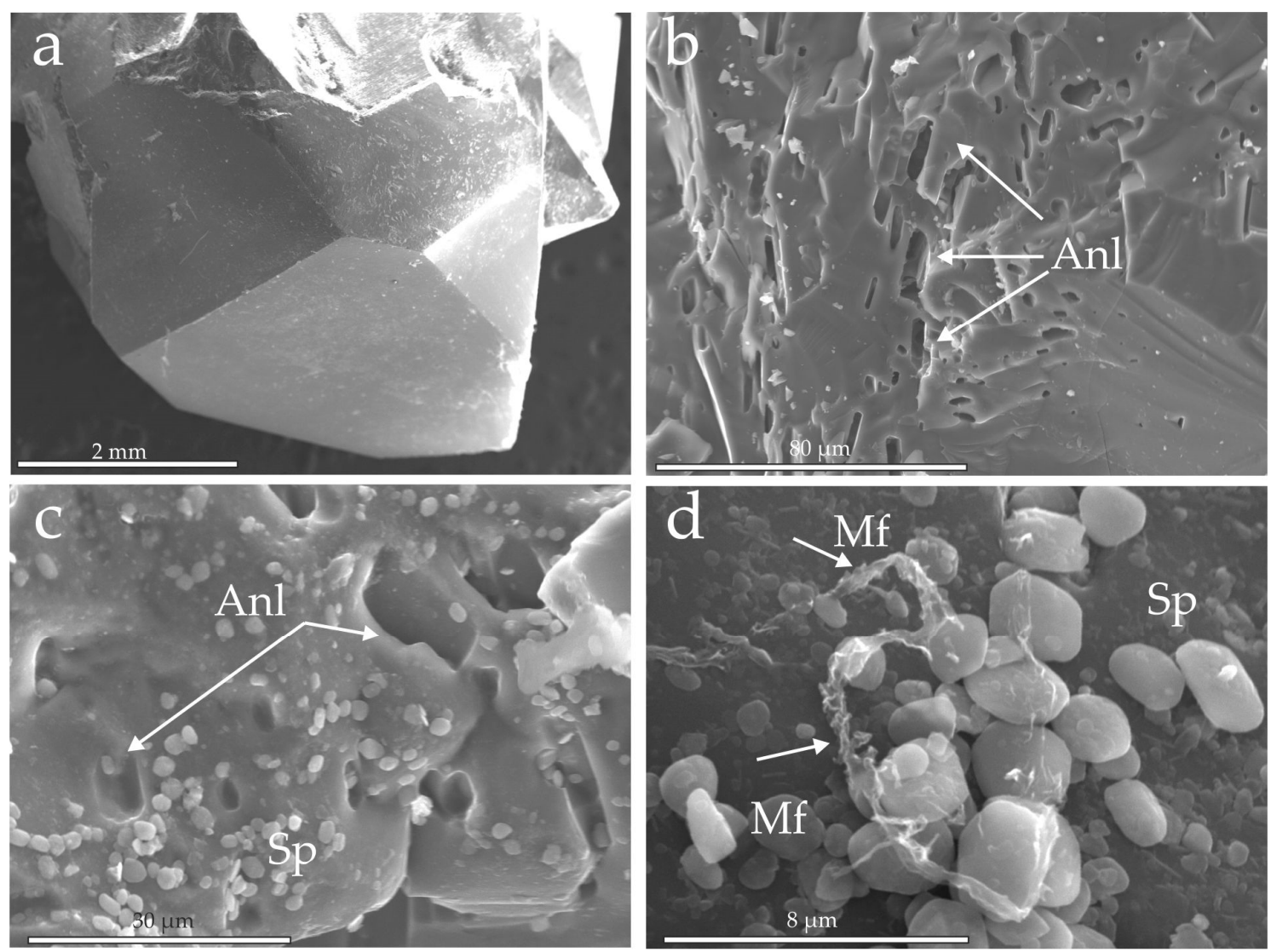

Figure 5. Scanning electron photomicrographs of Quartz (Q) crystals: (a) Idiomorphic edge of a bipyramidal quartz crystal with no signals of transport or dissolution; (b) High-resolution secondary electron images of quartz surface with abundant anhydrite laths (Anl); (c) Detail of the quartz central area of the quartz crystal with anhydrite laths, coated by quartz spherules (Sp); (d) Detail of the silica spherules (composed of $\mathrm{Si}, \mathrm{Fe}$, and $\mathrm{Al}$ ) and microbial filaments (Mf) indicating the formation of the quartz within a saline environment rich in organic matter.

SEM observations led as well to the identification of a layer of micron-sized quartz spherules (Sp in Figure 5c). These were coating surfaces of the siliceous nodule (Figure 5d) and were associated with organic filaments (Mf).

\subsection{Cathodoluminescence and Raman Spectra Analyses}

Cathodoluminiscence analyses highlighted the presence of concentric layers or bands around a nucleus (Figure 6a). The inner part of the crystal (silica nodule) had abundant inclusions and smooth shape. The center of the crystal under CL appeared as evaporitic minerals that had been replaced by silica (Figure 6b,c) [44]. Other pseudomorphs appeared as needle, laths (Figure. 6b,c), or nodule form. 

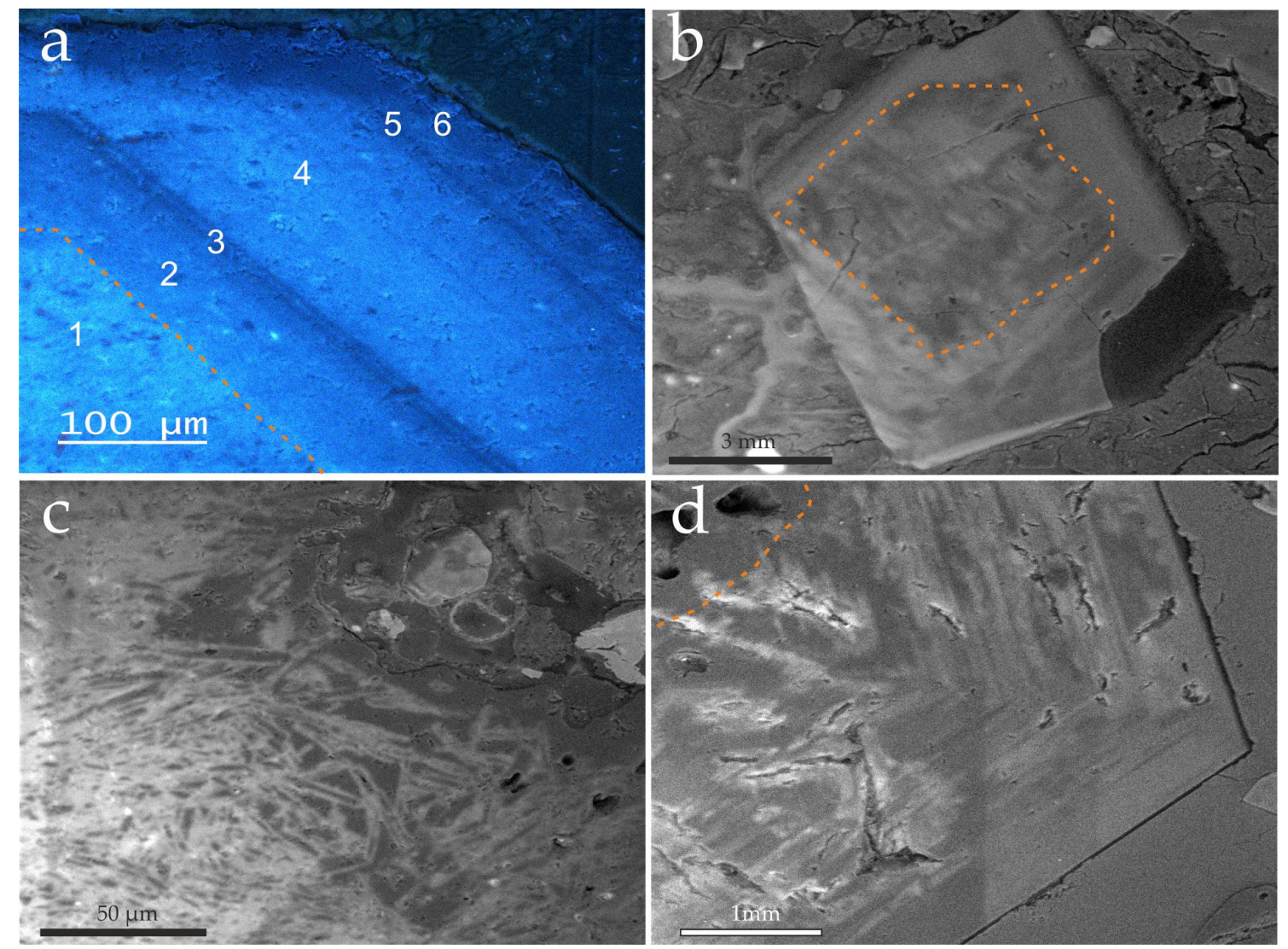

Figure 6. SEM-Cathodoluminescence (SEM-CL) analysis: (a) Light blue characterizes the luminescence response of the quartz crystals. Variation in the texture and color reveal changes between the center and the edges, separating the center, named silica nucleus (1) and five bands of quartz overgrowths (2-6); (b) The texture of the crystal reveal an irregular pattern in the center and a second phase of formation characterized by a regular overgrowth; (c) Detail of the center of the crystal (silica nucleus) showing quartz pseudomorphs after evaporite minerals (determined by SEM and microprobe analyses); the pseudomorphs appear either randomly oriented or subparallel to bedding; (d) The edges of the crystal appear as various bands, with variations in luminescence suggesting quartz overgrowth. To better distinguish textures, SEM-CL images are included in grey-scale colors.

Several thinner dark bands alternated with thicker lighter bands of quartz overgrowth over the silica nodule. (Figure $6 \mathrm{~b}, \mathrm{~d}$ ). Each lighter band followed the same pattern and direction as the previous darker band (Figure 6a,b,d). Laser Raman spectra of the center and outer part of bipyramidal quartz were obtained from different spots (Figure 7). The Raman spectra from three points of the central part of the crystal (Figure 7a,b) revealed the existence of quartz (Q), moganite (Mog), anhydrite (Anh), and polyhalite (Pol). Quartz and moganite both had similar Raman spectra which reflect they shared many structural elements [45]. The most intense quartz band appeared at $465 \mathrm{~cm}^{-1}$ while that of moganite was at $501 \mathrm{~cm}^{-1}$. Rodgers and Cressey [46] discriminated the two phases by the use of broad, low frequency, vibrational band present in the spectrum of quartz at $205 \mathrm{~cm}^{-1}$ and at a slightly higher frequency of moganite at $220 \mathrm{~cm}^{-1}$. The Raman spectra of four points from the external part of the crystal (Figure 7c,d) showed that there were only quartz and no moganite. The crystallinity in this part was higher, indicated by the sharper character of the Raman spectra picks towards the edges of the crystal. 

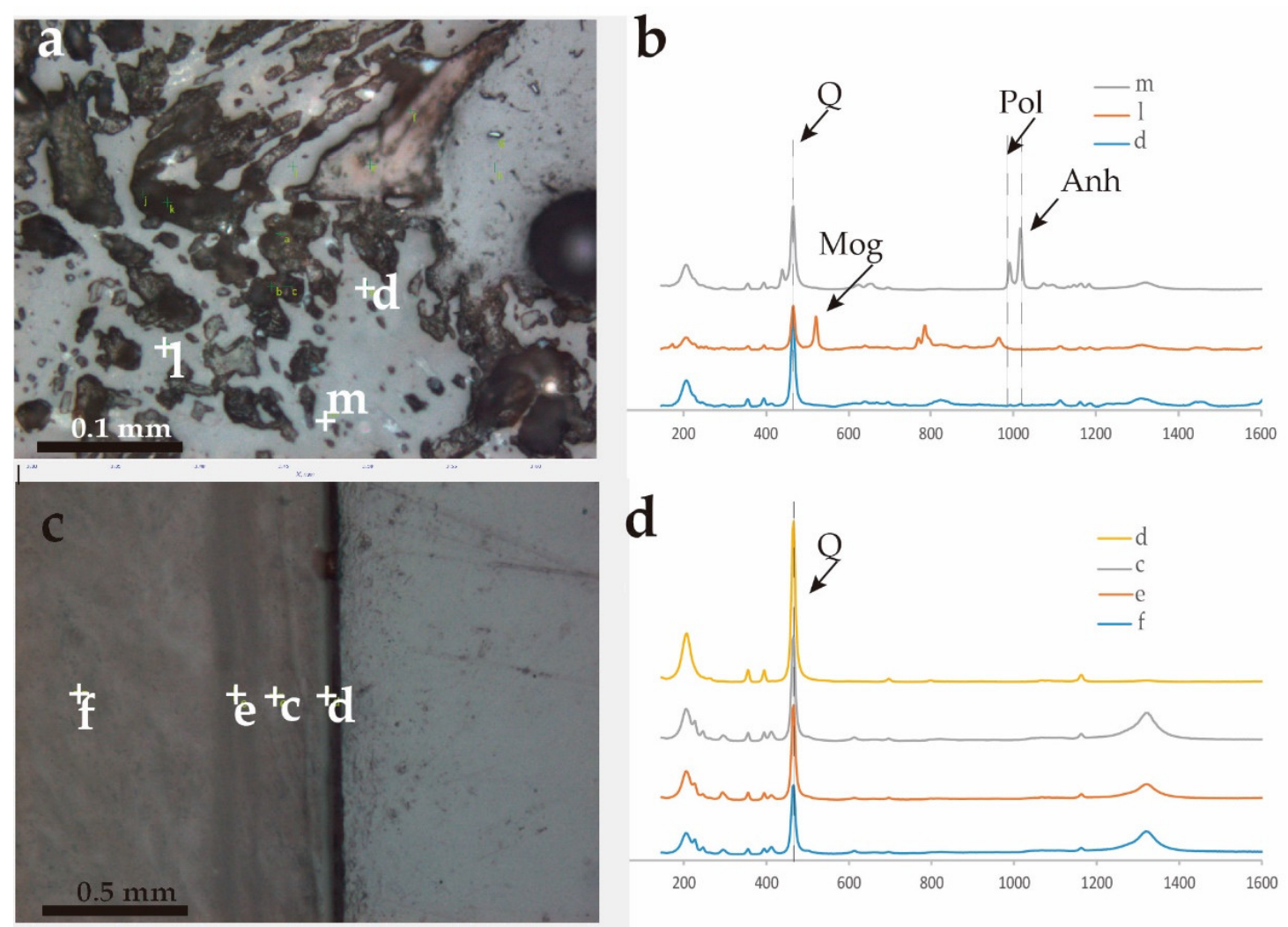

Figure 7. (a) Microphotograph showing the spots of measurement of Raman Spectrometry in the central part of euhedral quartz; (b) Image of Raman Spectra of micro-sampled spots d, 1 and m. Quartz (Q) appears together with moganite (Mog), anhydrite (Anh) and polyhalite (Pol); (c) Microphotograph showing the spots of measurement of Raman Spectrometry in the external part of a euhedral quartz; (d) Image of Raman Spectra of micro-sampled spots f, e, c and d. Quartz, in this case, was pure and more crystalline (X-axis represents Raman Shift $/ \mathrm{cm}^{-1}$ ).

\section{Discussion}

\subsection{Relationship between Doubly Terminated Quartz Crystals, Evaporites, Organic Matter, and Silica Sources}

The K4 facies of the Upper Triassic succession of the Iberian Basin [33] represents a saline mudflat in a clayey coastal plain environment with abundant shallow restricted Cl-rich brine salt ponds [47]. Salt pond deposits were composed of interlayered halite and mudstone beds with associated nodular anhydrite that formed a laterally extensive facies mosaic of sabkha and salinas across an evaporitic mudflat.

In the Iberian Basin, the authigenic bipyramidal quartz appears in scattered locations throughout the K4 facies of the Keuper succession (Figure 1) and does not show any concentration in a single layer or stratigraphic horizons indicating that they were not transported into the site of accumulation by aqueous currents. Euhedral quartz generally appears as crystals red or transparent, hyalines, doubly terminated crystals, and embedded in organic matter-rich crystals of white and black gypsum with abundant Fe-oxide and -hydroxides contents. Likewise, these quartz crystals also appear within mudstones and marls rich in chlorite, chlorite-smectite mixed layers, illite and scarce kaolinite [12]. The lithofacies where they appear are Mg-rich and poor in $\mathrm{Ca}$, interpreted as caused by the algal community present in the environment of sedimentation [48].

Euhedral quartz crystals, which were not corroded (Figures 3 and 5), had a central part composed of various crystals with undulose extinction and sutured boundaries. This central part had a large number of anhydrite and prismatic inclusions filled with organic matter, homogeneously spread in the crystals, although they disappeared towards the edges (Figures 3, 5 and 6). The ubiquitous presence 
of anhydrite inclusions (Figure $5 b$ ) and laths patterns, together with the organic matter inclusion in the center of the quartz crystals (Figure $5 c$ ), indicated a replacement of an anhydrite precursor with abundant organic matter in the environment. Some of the original mineral matter had been incorporated during this process. Moganite clearly showed up in the Raman spectra analysis (Figure 7a,b). This mineral was a metastable silica polymorph that was structurally similar to quartz [49], and commonly appeared associated with it in chert deposits formed in evaporitic environments [17]. Petrographic analyses also revealed the existence of silica phases filling voids in the center of the quartz crystal. This silica crystal must have grown in the dissolution cavities of the primary evaporite. The anhydrite nodules were probably partially dissolved by the interaction with meteoric water during a sea-level low-stand that occurred during the Upper Triassic [50]. As a result of sea level fluctuations, the waters in contact with the sediments changed from marine-derived evaporative/sabkha waters to meteoric in composition, and at some point, they became undersaturated with respect to anhydrite. This led to the evaporites' dissolution, which typically starts in the shallow subsurface, as salt beds are flushed by meteoric or marine waters and then continue deeper in the subsurface [15]. The most saline salts (typically halite and carnallite) undergo partial dissolution and are flushed, leaving behind residues of the less saline salts (typically gypsum-anhydrite). Pyrite and chalcopyrite crystals appeared associated with the replacive quartz and their presence was related to the metabolic activity of sulfate-reducing bacteria [51]. The environment of deposition was organic-rich and, in contact with the organic carbon, the sulfates (gypsum and anhydrite) would have been reduced to sulfides and, subsequently, oxidized in the near-surface environment of the sabkha. Oxidation of sulfides to sulfates would have decreased the $\mathrm{pH}$ of the waters and could have contributed to the precipitation of the available silica. The main factor controlling silica precipitation is the $\mathrm{pH}$ variations around 9 [52]. The solubility of silica dramatically increases when $\mathrm{pH}$ exceeds 9, and silica precipitates when $\mathrm{pH}$ falls to a lower value [17] when silica is available. Sources of silica could include the release of silica by clay transformations [53] and even silica introduced by springs and seeps [54,55] which are common in continental rift basins and volcanic regions, such as the Iberian Basin during the Upper Triassic [1,56].

The dissolution of sulfate crystals and precipitation of quartz occurred at a very shallow burial and low $\mathrm{pH}$ conditions during early diagenesis [57]. The quartz crystals started growing in void spaces created by the dissolution of evaporite minerals. Probably, the original quartz phase was the amorphous silica phase opal-A [58]. Miliken [11] determined that the anhydrite replacement by quartz in sabkhas takes place at temperatures that were $<40{ }^{\circ} \mathrm{C}$. During burial diagenesis, opaline phases age by undergoing successive dissolution-precipitation-recrystallization reactions, including the opal A-opal CT to quartz transition [58,59]. Quartz and lutecite (chalcedony) are common silica phases that typically replace previous anhydrite/gypsum nodules [60-62]. SEM observations led to the identification of micron-sized silica spherules (Figure $5 c$,d) partially coating the surfaces of the internal quartz nodule. Amorphous silica coated the surfaces of many detrital grains and appeared related to organic matter content [63]. They have been described as resulting from the volume for volume replacement of anhydrite nodules by microcrystalline quartz and quartz spherulites [11].

\subsection{Second Phase of Quartz Formation: Quartz Overgrowth}

Subsequent to silicification, these deposits were affected by diagenesis due to the downward percolation of meteoric waters and burial, generating dissolution of the nucleus and a phase of silica overgrowth.

Cathodoluminescence and petrographic analysis revealed that the silica nodule (that resulted from the replacement of an anhydrite nodule) appeared to have an irregular contour and an overgrowth composed of several layers, which appeared in the Raman spectrum as a more crystalline quartz phase with no moganite or evaporite mineral relicts (Figure $7 \mathrm{c}, \mathrm{d}$ ). The luminescence of the quartz crystals was blue (Figure 5a) and showed variations of texture: 1) the silica nucleus which showed pseudomorphs of the anhydrite precursor (the center); 2) a first band on top of the replacing silica (80 $\mu \mathrm{m}$ in thickness), which was bright in CL; 3) a thin CL dark band ( $c a 20 \mu \mathrm{m}$ thick); 4) another 
bright CL band, (150 $\mu \mathrm{m}$ thick); 5) a second dark band with ca 2-5 $\mu \mathrm{m}$ thickness; 6$)$ the last phase of overgrowth which was light in CL color and had a thickness of less than $60 \mu \mathrm{m}$. CL emissions in quartz indicated the specific physicochemical conditions of crystal growth and can be used as a signature of genetic conditions of mineral formation. The most common CL emission bands in natural quartz were the 450 and $650 \mathrm{~nm}[64,65]$, which resulted in bluish-violet CL colors and were detectable in quartz crystals from igneous, volcanic, and metamorphic rocks as well as authigenic quartz from sedimentary environments. The resulting CL analysis (Figure 5a) appeared similar to the authigenic quartz found in the Zechstein salt deposit of the Triassic of Germany [66].

These bands appeared as quartz overgrowths (syntaxial quartz cements). During the formation of quartz overgrowths in sandstones, relatively large quartz crystals (50-100 $\mathrm{mm}$ ) grew into pore spaces after burial, inheriting the exact crystallographic orientation of the detrital host grain upon which they have grown [67]. The silica needed to form the idiomorphic external part of the bipyramidal quartz in the Keuper facies could have resulted from the dissolution during the burial of part of the silicified anhydrite nodule. Organic acids, resulting from burial transformation of the organic matter present, could produce an increase in the solubility of quartz by bonding with silicic acids [68]. This organically mobilized silica precipitated as overgrowth around the siliceous nodule. Because silica is more soluble at high temperatures, the movement of silica-saturated solutions might be expected to be accompanied by growth variations. The temperature of formation of quartz overgrowths rarely takes place below $80{ }^{\circ} \mathrm{C}$ [69] and commonly appears in sandstones buried to depths where temperatures exceed 100 ${ }^{\circ} \mathrm{C}[68,70]$. Therefore, the initial temperature of the formation of the phase of quartz as overgrowth would be at a minimum of $c a 80^{\circ} \mathrm{C}$. Microprobe measurements of $\mathrm{Al}_{2} \mathrm{O}_{3}$ showed lower contents in the inner part of the crystals (Figure $4 \mathrm{a}-\mathrm{d}$ ) and a progressive rising towards the outer parts (Figure $4 \mathrm{~b}$ ). In the present study, the slight change in $\mathrm{Al}_{2} \mathrm{O}_{3}$ content in the quartz is considered to be indicative of variation in the temperature of formation, rising towards the edges [71]. Among temperature, other factors controlling silica formation include $\mathrm{pH}$ higher than 5 and changes in the chemistry of the pore-water, which could lead to variations of composition reflected in the CL bands [70].

\subsection{Relation of the Bipyramidal Quartz with the Aragonite Presence in the Keuper Facies}

In this work, the origin of bipyramidal quartz in the K4 unit of the Keuper facies in the Iberian Basin is described [33]. In these same facies, pseudohexagonal crystals of aragonite appear at some locations as well. The presence of aragonite seems to be related to saline pond environments where $\mathrm{Mg}$-rich clay minerals originated [72]. Around 80\% of the aragonite crystals outcrops are concentrated in three areas and their occurrence defines an NW to SE lineation [1] from north-central Spain to the Eastern Iberian Peninsula (Figure 10 in Reference [1]). These three areas coincide with the location of volcanic materials that correspond to a pre-Hettangian magmatic episode [56,73] coeval to the second period of intense synrift magmatic activity in the Iberian Basin [56].

The occurrence of aragonite is as well coincident with a set of normal faults of Middle-to-Upper Jurassic age (154-144 Ma) [74]. These faults resulted from a tectonic extensional episode which occurred at the same time interval as an important hydrothermal event (150 Ma) defined in the Eastern Iberian Central System, just west of the Iberian Basin. This hydrothermal event was caused by fluids that circulated within regional-scale convective cells. The fluids flowed along the Middle-to-Upper Jurassic faults, and they mixed with downwards percolating brines [75]. The mixing of these fluids through the $\mathrm{K} 4$ unit of the Keuper produced the transformation of the Mg-rich smectite into corrensite and lead to the precipitation of the aragonite [1]. Fluid inclusions analyses led to determine the temperatures of formation ranging between 160 and $260{ }^{\circ} \mathrm{C}$ [1].

The aragonite crystals were commonly engulfing corrensite but also euhedral quartz crystals, suggesting a temporal relationship [1]. Therefore, the bipyramidal quartz resulted from an early diagenetic evaporitic mineral replacement by silica, at temperatures of less than $40{ }^{\circ} \mathrm{C}$ and lately, mesodiagenetic quartz overgrowths formed at temperatures between 80 and $100{ }^{\circ} \mathrm{C}$. Both quartz phases were formed during the rifting period of the Upper Triassic. On the other hand, aragonite was 
precipitated 40 Ma later during Callovian times, resulting from the mixing of hydrothermal fluids with infiltrated marine waters at temperatures ranging between 160 and $260^{\circ} \mathrm{C}$ [1].

\section{Conclusions}

Euhedral quartz, in the form of individual doubly terminated crystals, appear throughout Upper Triassic evaporite-bearing sabkha deposits (K4) in the Iberian Basin.

Optical microscopy, SEM, microprobe, SEM-CL, XRD, and Raman spectra analyses performed in the bipyramidal quartz crystals revealed differences in formation between the inner and outer part of the crystals.

The inner part of the quartz crystals resulted from a replacement of anhydrite nodules that formed in a sabkha environment. Meteoric waters repeatedly flushed the sabkha deposits and dissolved some of the evaporitic minerals, producing relatively large pore spaces into which silica precipitated. Organic rich contents and the action of sulfate-reducing bacteria that transformed part of the sulfates into sulfides produced variations of $\mathrm{pH}$ that promoted silica precipitation. The replacement of evaporites by quartz occurred at a very shallow burial, low $\mathrm{pH}$, and temperatures of less than $40{ }^{\circ} \mathrm{C}$, soon after deposition.

The organic matter left in the inclusions was transformed with burial and generated organic acids that produced the dissolution of the siliceous nodule. This organically mobilized silica eventually precipitated as overgrowths, at temperatures between 80 and $100^{\circ} \mathrm{C}$, indicating that quartz overgrowth was generated during the mesodiagenesis. The slight change in $\mathrm{Al}_{2} \mathrm{O}_{3}$ content from the center to the outer part of the crystal also indicates the rising of the temperature of formation.

The Upper Triassic succession was affected by the reactivation of alpine NW-SE trending fractures during the Callovian, $40 \mathrm{Ma}$ later. These fractures served as conduits for hydrothermal fluid that mixed with infiltrated marine waters and produced important transformations of Mg-rich smectite into corrensite and lead to the precipitation of the aragonite at temperatures between 160 and $260{ }^{\circ} \mathrm{C}$.

Hence, crystals of compositions as different as quartz and aragonite, occurring within the same sedimentary succession and depositional environment, indicate different formation fluids, temperature regimes, and diagenetic, tectonic, and thermal stages within the geological history of the Iberian Basin.

This study demonstrates a great example of how a detailed establishment of the origin of different mineral phases within a sedimentary succession permits unraveling an accurate reconstruction of a basin's evolution.

Author Contributions: Conceptualization, M.J.H. and M.S.; Data curation, M.S.; Formal analysis, R.M. and J.I.E.; Funding acquisition, M.J.H. and I.A.-A.; Investigation, M.J.H., R.M., J.I.E., I.A.-A., and M.S.; Methodology, M.J.H., R.M., and J.I.E.; Project administration, M.J.H.; Software, J.I.E. and M.S.; Supervision, M.J.H.; Validation, I.A.-A.; Writing—original draft, M.J.H., R.M., J.I.E., and M.S.; Writing—review and editing, M.J.H. and R.M. All authors have read and agreed to the published version of the manuscript.

Funding: This research was funded by Projects FEI16/52-4159070 and 4157047 of the Fundación UCM.

Acknowledgments: We are grateful to A. Rodriguez from the CNME of the UCM for his assistance with the SEM studies and to M. Barajas and P. Lozano for the thin sections' preparation. SEM-Catodoluminescence was performed at the CAI de Ciencias Geológicas, and we would like to acknowledge X. Arroyo for assistance. We would like to thank the reviewers and the editorial team for their comments and suggestions that have led to improvements in the manuscript. Ihsan Al-Aasm acknowledges the continuous support by NSERC.

Conflicts of Interest: The authors declare no conflict of interest.

\section{References}

1. Herrero, M.J.; Marfil, R.; Escavy, J.I.; Scherer, M.; Arroyo, X.; Martín-Crespo, T.; López de Andrés, S. Hydrothermal activity within a sedimentary succession: Aragonites as indicators of Mesozoic Rifting (Iberian Basin, Spain). Int. Geol. Rev. 2020, 62, 94-112. [CrossRef]

2. Chafetz, H.S.; Zhang, J. Authigenic Euhedral Megaquartz Crystals in a Quaternary Dolomite. J. Sediment. Pet. 1998, 68, 994-1000. [CrossRef] 
3. Winsborough, B.M.; Seeler, J.S.; Golubic, S.; Folk, R.L. Recent fresh-water lacustrine stromatolites, stromatolitic mats and oncoids from northeastern Mexico. In Phanerozoic Stromatolites II; Bertrand-Sarfati, J., Monty, C., Eds.; Kluwer Academic Publishers: Dordrecht, The Netherlands, 1994; pp. 71-100.

4. Folk, R.L. Petrography and petrology of the Lower Ordovician Beekmantown carbonate rocks in the vicinity of State College. Ph.D. Thesis, Pennsylvania State University, Pennsylvania, PA, USA, 1952.

5. Friedman, G.M.; Shukla, V. Significance of authigenic quartz euhedra after sulfates: Example from the Lockport Formation (Middle Silurian) of New York. J. Sediment. Res. 1980, 50, 1299-1304.

6. Wilson, R.C.L. Silica diagenesis in Upper Jurassic limestones of Southern England. J. Sediment. Pet. 1966, 36, 1036-1049.

7. Zenger, D.H. Definition of type Little Falls Dolostone (Late Cambrian), east-central New York. Am. Assoc. Pet. Geol. Bull. 1976, 60, 1570-1575.

8. Scholle, P.A. A Color Illustrated Guide to: Constituents, Textures, Cements, and Porosities of Sandstones and Associated Rocks. Am. Assoc. Pet. Geol. 1979, 27, 201.

9. Folk, R.L.; Pittman, J.S. Length-slow chalcedony: A new testament for vanished evaporites. J. Sediment. Pet. 1971, 41, 1045-1058.

10. Friedman, G.M. Dissolution-collapse breccias and paleokarst resulting from dissolution of evaporite rocks, especially sulfates. Carbonates Evaporites 1997, 12, 53-63. [CrossRef]

11. Milliken, K.L. The silicified evaporite syndrome-Two aspects of silicification history of former evaporite nodules from southern Kentucky and northern Tennessee. J. Sediment. Pet. 1979, 49, 245-256.

12. Marfil, R. Estudio Petrogenético del Keuper en el sector meridional de la Cordillera Ibérica. Estudios Geológicos 1970, 24, 113-161.

13. Calvo Rebollar, M. Minerales Y Minas De España. Volumen VIII: Cuarzo Y Otros Minerales De La Silice; Fundación Gómez-Pardo: Madrid, Spain, 2016; p. 399.

14. Knauth, L.P. Petrogenesis of chert. In Silica, Physical Behavior, Geochemistry and Materials Application; Heaney, P.J., Prewitt, C.T., Gibbs, G.V., Eds.; Mineralogical Society of America: Chantilly, VA, USA, 1994; Volume 29, pp. 233-258.

15. Warren, J.K. Evaporites: A Geological Compendium; Springer: Berlin/Heidelberg, Germany, 2016; p. 1816.

16. Scotford, D.M. A Test of Aluminum in Quartz as a Geothermometer. Am. Mineral. 1975, 60, 139-142.

17. Bustillo, M.A. Silicification of Continental Carbonates. In Developments in Sedimentology; Alonso-Zarza, A.M., Tanner, L.H., Eds.; Elsevier: Amsterdam, The Netherlands, 2010; Volume 62, pp. 153-178.

18. Goudie, A.; Calcrete, S.; Goudie, A.S. Chemical Sediments and Geomorphology; Goudie, A.S., Pye, K., Eds.; Academic Press: London, UK, 1983; pp. 93-131.

19. Arche, A.; López-Gómez, J. Origin of the Permian-Triassic Iberian Basin, central-eastern Spain. Tectonophysics 1996, 266, 443-464. [CrossRef]

20. Sopeña, A.; López-Gómez, J.; Arche, A.; Pérez-Arlucea, M.; Ramos, A.; Virgili, C.; Hernándo, S. Permian and Triassic rift basins of the Iberian Peninsula. In Triassic-Jurassic Rifting-Continental Breakup and the Origin of the Atlantic Ocean and Passive Margins; Manspeizer, W., Ed.; Elsevier: Amsterdam, The Netherlands, 1988; Volume 22B, pp. 757-786.

21. Van Wees, J.D.; Arche, A.; Beijdorff, C.G.; López-Gómez, J.; Cloetingh, S. Temporal and spatial variations in tectonic subsidence in the Iberian Basin (eastern Spain): Inferences from automated forward modelling of high-resolution stratigraphy (Permian-Mesozoic). Tectonophysics 1998, 300, 285-310. [CrossRef]

22. Vargas, H.; Gaspar-Escribano, J.; López-Gómez, J.; Van Wees, J.D.; Cloetingh, S.; De la Horra, R.; Arche, A. A comparison of the Iberian and Ebro Basins during the Permian and Triassic, eastern Spain: A quantitative subsidence modelling approach. Tectonophysics 2009, 474, 160-183. [CrossRef]

23. Salas, R.; Guimerà, J.; Mas, R.; Martín-Closas, C.; Meléndez, A.; Alonso, A. Evolution of the Mesozoic Central Iberian Rift System and its Cainozoic inversion (Iberian Chain). In Peri-Tethys Memoir 6: Peri-Tethyan Rift/Wrench Basins and Passive Margins; Ziegler, P.A., Cavazza, W., Robertson, A.H., Crasquin-Soleau, F., Eds.; Muséum National Histoire Naturelle: Paris, France, 2001; pp. 145-185.

24. Sopeña, A.; Sánchez-Moya, Y. Tectonic systems tract and depositional architecture of the western border of the Triassic Iberian Trough (central Spain). Sediment. Geol. 1997, 113, 245-267. [CrossRef]

25. Sánchez-Moya, Y.; Sopeña, A. El rift Mesozoico Ibérico. In Geología de España; Vera, J.A., Ed.; SGE-IGME: Madrid, Spain, 2004; pp. 484-522. 
26. Rosembaum, G.; Lister, G.S.; Duboz, C. Relative motions of Africa, Iberia and Europe during Alpine orogeny. Tectonophysics 2002, 359, 117-129. [CrossRef]

27. López-Gómez, J.; Alonso-Azcárate, J.; Arche, A.; Arribas, J.; Fernández Barrenechea, J.; Borruel-Abadía, V.; Bourquin, S.; Cadenas, P.; Cuevas, J.; De la Horra, R.; et al. Permian-Triassic Rifting Stage. In The Geology of Iberia: A Geodynamic Approach; Quesada, C., Oliveira, T., Eds.; Springer: Berlin/Heidelberg, Germany, 2019; Volume 3, pp. 29-112.

28. De Vicente, G.; Vegas, R.; Muñoz-Martín, A.; Van Wees, J.D.; Casas-Sainz, A.M.; Sopeña, A.; Sánchez-Moya, Y.; Arche, A.; López-Gómez, J.; Olaiz, A.; et al. Oblique strain partitioning and transpression on an inverted rift: The Castilian Branch of the Iberian Chain. Tectonophysics 2009, 470, 224-242. [CrossRef]

29. Murphy, J.B.; Nance, R.D.; Cawood, P.A. Contrasting modes of supercontinent formation and the conundrum of Pangea. Gondwana Res. 2009, 15, 408-420. [CrossRef]

30. Ziegler, P.A.; Stamplfli, G.M. Late Paleozoic-early Mesozoic plate boundary reorganization, collapse of the variscan orogeny and opening of neotethys. In Permian Continental Deposits of Europe and other Areas. Regional Reports and Correlations; Cassinis, G., Ed.; Museo Civico Science Naturali: Brescia, Italy, 2001; Volume 25, pp. 17-34.

31. López-Gómez, J.; Arche, A.; Pérez-López, A. Permian and Triassic. In The Geology of Spain; Gibbons, W., Moreno, T., Eds.; The Geological Society: London, UK, 2002; pp. 185-212.

32. Sopeña, A.; Gutiérrez-Marco, J.C.; Sánchez-Moya, Y.; Gómez, J.J.; Mas, J.R.; García, A.; Lago, M. Cordillera Ibérica y Costero Catalana. In Geología de España; Vera, J.A., Ed.; SGE-IGME: Madrid, Spain, 2004; pp. 465-527.

33. Ortí, F.; Pérez-López, A.; Salvany, J.M. Triassic evaporites of Iberia: Sedimentological and palaeogeographical implications for the western Neotethys evolution during the Middle Triassic-Earliest Jurasic. Palaeogeogr. Palaeoclimatol. Palaeoecol. 2017, 471, 157-180. [CrossRef]

34. Suarez Alba, J. La Mancha Triassic and Lower Lias stratigraphy, a well log interpretation. J. Iber. Geol. 2007, 33, 55-78.

35. Arche, A.; López-Gómez, J.; García-Hidalgo, J.F. Control climático, tectónico y eustático en depósitos del Carniense (Triásico Superior) del SE de la Península Ibérica. J. Iber. Geol. 2002, 28, 13-30.

36. Ortí, F.; García-Veigas, J.; Rosell Ortiz, L.; Jurado, M.J.; Utrilla, R. Formaciones salinas de las cuencas triásicas en la Península Ibérica: Caracterización petrológica y geoquímica. Cuadernos De Geología Ibérica 1996, 20, 13-35.

37. Escavy, J.I.; Herrero, M.J. The use of location-allocation techniques for exploration targeting of high place-value industrial minerals: A market-based prospectivity study of the Spanish gypsum resources. Ore Geol. Rev. 2013, 53, 504-516. [CrossRef]

38. Escavy, J.I.; Herrero, M.J.; Arribas, M.E. Gypsum resources of Spain: Temporal and spatial distribution. Ore Geol. Rev. 2012, 49, 72-84. [CrossRef]

39. Goy, A.; Martínez, G.; Pérez-Valera, F.; Pérez-Valera, J.A.; Trigueros-Ramos, L.M. Nuevos hallazgos de Cefalópodos (Ammonoideos y Nautiloideos) del Ladiniense Inferior en el sector oriental de las Cordillera Béticas. Boletín de la Real Sociedad Española de Historia Natural 1996, 125, 311-314.

40. Lago, M.; Dumitrescu, R.; Bastida, J.; Arranz, E.; Gil-Imaz, A.; Pocovi, A.; Lapuente, M.P.; Vaquer, R. Características de los magmatismos alcalino y subalcalino, pre-Hettangiense, del borde SE de la Cordillera Ibérica. Cuadernos De Geología Ibérica 1994, 20, 159-181.

41. Chun, F.H. Quantitative interpretation of X-ray diffraction patterns of mixtures. III. simultaneous determination of a set of reference intensities. J. Appl. Chrystallogr. 1975, 8, 17-19. [CrossRef]

42. Zinkernagel, U. Cathodoluminescence of quartz and its application to sandstone petrology. Contrib. Sedimentol. 1978, 8, 1-69.

43. Matter, A.; Ramseyer, K. Cathodoluminescence Microscopy as A Tool for Provenance Studies of Sandstones. In Provenance of Arenites; Zuffa, G.G., Ed.; Reidel: Boston, MA, USA, 1985; pp. 191-211.

44. El Tabakh, M.; Grey, K.; Pirajno, F.; Schreiber, B.C. Pseudomorphs after evaporitic minerals interbedded with 2.2 Ga stromatolites of the Yerrida basin, Western Australia: Origin and significance. Geology 1999, 27, 871-874. [CrossRef]

45. Kingma, K.J.; Hemley, R.J. Raman spectroscopic study of microcrystalline silica. Am. Miner. 1994, 79, 269-273.

46. Rodgers, K.A.; Cressey, G. The occurrence, detection and significance of moganite $\left(\mathrm{SiO}_{2}\right)$ among some silica sinters. Miner. Mag. 2001, 65, 157-167. [CrossRef] 
47. Del Olmo, P.; Olivé, A.; Gutiérrez, M.; Aguilar, M.J.; Leal, M.C.; Portero, J.M. Hoja geológica 438 (Paniza). In Mapa Geológico de España, E. 1:50.000; Segunda Serie I.G.M.E.: Madrid, Spain, 1983.

48. Castaño, R.; Doval, M.; Marfil, R. Naturaleza, origen y distribución de los minerales de la arcilla en la cuenca Triásica (Keuper) del área de Valencia. Cuadernos de Geología Ibérica 1987, 11, 339-361.

49. Miehe, G.; Graetsch, H.; Flörke, O.W. Crystal structure and growth fabric of length-fast chalcedony. Phys. Chem. Miner. 1984, 10, 197-199. [CrossRef]

50. Sánchez-Moya, Y.; Herrero, M.J.; Sopeña, A. Strontium isotopes and sedimentology of a marine Triassic succesion (upper ladinian) of the westernmost Tethys, Spain. J. Iber. Geol. 2016, 42, 171-186.

51. Palmer, S.E. Effect of Biodegradation and Water Washing On Crude Oil Composition. In Organic Geochemistry: Principles and applications; Engel, M.H., Macko, S.A., Eds.; Springer: Berlin/Heidelberg, Germany, 1993; Volume 11, pp. 511-533.

52. Siever, R. Silica solubility $0-200{ }^{\circ} \mathrm{C}$ and the diagenesis of siliceous sediments. J. Geol. 1962, 70, $127-150$. [CrossRef]

53. Mahran, T.M. Late Oligocene lacustrine deposition of the Sodmin Formation, Abu Hammad Basin, Red Sea, Egypt; sedimentology and factors controlling palustrine carbonates. J. Afr. Earth Sci. 1999, 29, 567-592. [CrossRef]

54. De Wet, C.C.; J. F.; H. The Scots Bay Formation, Nova Scotia, a Jurassic carbonate lake with silica-rich hydrothermal springs. Sedimentology 1989, 36, 857-875. [CrossRef]

55. Smith, A.M.; Mason, T.R. Pleistocene, multiple-growth, lacustrine oncoids from the Poacher's Point Formation, Etosha Pan, northern Namibia. Sedimentology 1991, 38, 591-599. [CrossRef]

56. Lago, M.; Arranz, E.; Gil, A.; Pocovi, A. Cordilleras Ibérica y Costero-Catalana; Magmatismo Asociado. In Geología de, España, Vera, J.A., Eds.; SGE-IGME: Madrid, Spain, 2004; p. 890.

57. Maliva, R.G.; Siever, R. Nodular chert formation in carbonate rocks. J. Geol. 1989, 97, 421-433. [CrossRef]

58. Williams, L.A.; Parks, G.; Crerar, D.A. Silica diagenesis, I. Solubility controls. J. Sediment. Pet. 1985, 55, 301-311.

59. Williams, L.A.; Crerar, D.A. Silica diagenesis II. General mechanisms. J. Sediment. Pet. 1985, 55, 312-321.

60. Alonso-Zarza, A.M.; Sánchez-Moya, Y.; Bustillo, M.A.; Sopeña, A.; Delgado, A. Silicification and dolomitization of anhydrite nodules in argillaceous terrestrial deposits: An example of meteoric-dominated diagenesis from the Triassic of central Spain. Sedimentology 2002, 49, 303-317. [CrossRef]

61. Arbey, F. Les formes de la silice et l'identification des évaporites dans les formations silicifiées. Bulletin des Centres de Recherche, Exploration-Production Elf Aquitaine 1980, 4, 309-365.

62. Hesse, R. Silica diagenesis: Origin of inorganic and replacement cherts. Earth-Sci. Rev. 1989, 26, $253-284$. [CrossRef]

63. Rimstidt, J.D.; Barnes, H.L. The kinetics of silica-water reactions. Geochimica et Cosmochimica Acta 1980, 44, 1683-1699. [CrossRef]

64. Götze, J.; Plötze, M.; Tichomirowa, M.; Fuchs, H.; Pilot, J. Aluminium in quartz as an indicator of the temperature of formation of agate. Miner. Mag. 2001, 65, 407-413. [CrossRef]

65. Ramseyer, K.; Baumann, J.; Matter, A.; Mullis, J. Cathodoluminescence colours of alpha-quartz. Miner. Mag. 1988, 52, 669-677. [CrossRef]

66. Götze, J. Mineralogy, Geochemistry and cathodoluminescence of authigenic quartz from different sedimentary rocks. In Quartz: Deposits, Mineralogy and Analytics; Götze, J., Möckel, R., Eds.; Springer: Berlin/Heidelberg, Germany, 2012; pp. 287-306.

67. Waugh, B. Formation of quartz overgrowths in Penrith Sandstone (Lower Permian) of northwest England as revealed by scanning electron microscopy. Sedimentology 1970, 14, 309-320. [CrossRef]

68. French, M.W.; Worden, R.H.; Mariani, E.; Larese, R.E.; Mueller, R.R.; Kliewer, C.E. Microcrystalline Quartz Generation and the Preservation of Porosity in Sandstones: Evidence from the Upper Cretaceous of the Subhercynian Basin, Germany. J. Sediment. Res. 2012, 82, 422-434. [CrossRef]

69. Wilkinson, M.; Haszeldine, R.S. Fibropus illite in oilfield sandstones-A nucleation kinetic theory of growth. Terra Nova 2002, 14, 56-60. [CrossRef]

70. Worden, R.H.; Morad, S. Quartz cementation in oil field sandstones: A review of the key controversies. Spec. Publ. Int. Assoc. Sedimentol. 2000, 29, 1-20.

71. Dennen, W.H.; Blackburn, W.H.; Quesada, A. Aluminium in quartz as a geothermometer. Contrib. Miner. Pet. 1970, 27, 32-42. [CrossRef] 
72. García Palacios, M.C.; Lucas, J.; De la Peña, J.A.; Marfil, R. La Cuenca Triásica de la Rama Castellana de la Cordillera Ibérica. I Petrografía y Mineralogía. Cuadernos de Geología Ibérica 1977, 4, 341-354.

73. Lago, M.; Pocovi, A.; Bastida, J.; Arranz, E.; Vaquer, R.; Dumitrescu, R.; Gil-Imaz, A.; Lapuente, M.P. El magmatismo alcalino, hettangiense, en el dominio nor-oriental de la Placa Ibérica. Cuadernos de Geología Ibérica 1996, 20, 109-138.

74. Dercourt, J.; Gaetani, M.; Vrielynck, B.; Barrier, E.; Biju-Duval, B.; Brunet, M.F.; Cadet, J.P.; Crasquin, S.; Sandulescu, M. Atlas or Peri-Tethys. Paleeogeographical Maps; Commission for the Geological Map of the World: Paris, France, 2000; p. 268.

75. Tornos, F.; Spiro, B.F. The Geology and Isotope Geochemistry of the Talc Deposits of Puebla de Lillo (Cantabrian Zone, Northern Spain). Econ. Geol. 2000, 95, 1277-1296. [CrossRef]

(C) 2020 by the authors. Licensee MDPI, Basel, Switzerland. This article is an open access article distributed under the terms and conditions of the Creative Commons Attribution (CC BY) license (http://creativecommons.org/licenses/by/4.0/). 